\title{
Zakat dan Pajak: Perbandingan Malaysia dan Indonesia
}

\author{
Ro'yun Niswati Ahada*, Tutik Hamidah \\ Universitas Islam Negeri Maulana Malik Ibrahim Malang, Indonesia \\ royunnahada@gmail.com
}

Copyright (C) 2021 The Author

This is an open access article

Under the Creative Commons Attribution-ShareAlike 4. 0 International License

\begin{abstract}
Zakat and tax are two things that are obligatory in the field of property, but they also have different philosophies, principles and characteristics. Zakat is part of the assets that must be issued by Muslims, while taxes are mandatory contributions by the people to the state and must be paid to the state in accordance with the rules that have been decided by the government. Here the researcher discusses the implementation of zakat and comparative taxes between Malaysia and Indonesia. This research uses literature study method with qualitative approach. Zakat and Taxes in Malaysia are managed by the central government through the territory of the respective states. Also, zakat is claimed to be a deduction from tax obligations, if the muzaki pays zakat at the Zakat Collection Center then, there is a reduction in zakat for tax reduction. Meanwhile in Indonesia, Zakat is managed by the Amil Zakat Agency and the Amil Zakat Institution formed by the Government. There is a regulation between zakat and taxes, in which there is a deduction of zakat and taxes if the zakat is deposited by muzaki through BAZNAS or LAZ by including proof of tax payment.
\end{abstract}

Keywords: zakat; tax; malaysia; indonesia

\begin{abstract}
ABSTRAK
Zakat dan Pajak merupakan dua hal kewajban dalam bidang harta, akan tetapi juga memiliki filosofis, asas, dan sifat yang berbeda. Zakat adalah sebagian harta yang wajib dikeluarkan oleh umat muslim, sedangkan pajak adalah iuran wajib oleh rakyat kepada negara dan harus dibayarkan ke Negara sesuai dengan aturan yang sudah diputuskan oleh pemerintah. Seorang muslim wajib membayar zakat, dan seorang warna bernegara juga wajib untuk membayar zakat. Di sini peneliti membahas pelaksanaan zakat dan pajak perbandingan antara Malaysia dan Indonesia. Dalam enelitian ini menggunakan metode studi literature dengan jenis pendekatan kualitatif. Zakat dan Pajak di Malaysia dikelola oleh pemintah pusat melalui wilayah negara bagian masing-masing. Juga, zakat diklaim bisa menjadi pengurang atas kewajiban pepajakan, jika muzaki membayarkan zakat pada Pusat Pemungutan Zakat maka, ada pengurangan zakat untuk pengurangan pajak. Sedang di Indonesia, Zakat dikelola oleh Badan Amil Zakat dan Lembaga Amil Zakat yang dibentuk oleh Pemerintah. Terdapat regulasi antara zakat dan pajak, yang mana terdapat pemotongan zakat dan pajak apabila zakat yang disetorksn oleh muzaki melalui BAZNAS atau LAZ dengan menyertakan bukti setoran pajak.
\end{abstract}

Kata Kunci: zakat; pajak; malaysia; indonesia 


\section{A. PENDAHULUAN}

Pada zaman dahulu pemerintah Islam mengelola zakat, yang mana Zakat adalah salah satu pendapatan Negara yang terbesar dan dikelola oleh Baitulmaal. Baitulmaal merupakan sebuah lembaga yang memegang kuasa mengenai setiap harta dan benda kaum muslimin, baik berbentuk pemasukan ataupun pengeluaran Negara. Baitulmaal sendiri telah ada sejak zaman Rasulullah saw.

Zakat dan pajak yang mana dalam keduanya terdapat kewajiban dibidang harta, namun juga memiliki filosofi tersendiri dan juga memilik perbedaan asas, sifat sumber sasaran juga bagian kadar. Zakat sendiri memiliki posisi yang lebih tinggi bagi umat Islam bila dibandingkan dengan fiskal modern keungan dan pajak, baik secara prinsip maupun secara hukum.

Sebagian besar Negara di dunia telah menggunakan pajak menjadi alat penting untuk melengkapi kepentingan Negara. Oleh karena itu Pajak sebagai keharusan yang wajib dibayarkan oleh seluruh warga negara sebagai sumber pendapatan negara. Dalam hal ini, untuk melaksanakan pembangunan yang mana membutuhkan dana guna mencukupi kebutuhan dan hal-hal yang dibutuhkan, dari situlah pemerintah mewajibkan pajak kepada masyarakat sehingga pajak menjadi kewajiban bagi masyarakat bernegara (Murtadho, 2014).

Akan tetapi selain memiliki keharusan akan pelunasan pajak, seorang warga negara Muslim juga mempunyai keharusan lain yang harus dibayarkan, yakni membayar Zakat. Tentunya bagi masyarakat muslim bukan hal yang mengherankan dengan rukun Islam ke tiga ini. Zakat sendiri merupakan bentuk nyata dari sebuah interaksi yang kuat antar manusia yang mana sebagai makhluk sosial dan mendorong untuk berusaha mendapatkan kekayaan, sehingga bisa digunakan untuk bukti dari pelakasanaan kewajiban rukun Islam yang ketiga yang berupa membayar Zakat.

Menurut etimologi, pajak bahasa arabnya disebut dharibah memiliki arti kewajiban, ketetapan, ketentuan, pukulan, penerangan dan sebagainya (Edi, 2020).

Sedangkan secara terminologis zakat yaitu sejumlah harat tertentu yang diwajibkan oleh Allah swt. dan diserahkan untuk orang-rang yang berhak menerimanya (Fathurrahaman, 2009).

Jika seseorang membayarkan zakatnya maka mendapatkan kebaikan sangat banyak, sebagaimana dalam firman Allah swt. Surat At-Taubah Ayat 103:

Artinya: "Ambillah zakat dari harta mereka, guna membersihkan dan menyucikan mereka, dan berdo'alah untuk mereka. Sesungguhnya do'amu itu nebumbuhkan ketentraman jiwa bagi mereka. Allah maha mendengar, Maha mengetahui”. (AlQur'an).

Berdasarkan ahli fiqih zakat yaitu suatu kewajiban tertentu yang di wajibkan oleh Allah swt. terhadap harta kaum muslimin yang ditujukan kepada mereka yang berhak, sebagaimana dalam Al-Qur'an disebutkan yakni fakir miskin dan mustahik lainnya sebagai bentuk rasa syukur atas nikmat Allah swt. dan untuk mendekatkan diri kepada Allah, serta untuk mesucikan diri dan juga hartanya (Didin, 2008). 
Prof. Dr. P.J.A. Adriani menyatakan bahwa pajak merupakan kontribusi publik yang dilakukan oleh masyarakatan kepada sistem yang harus dibayar rakyat sesuai dengan ketentuan undang-undang dan digunakan untuk pembiayaan umum yang berkaitan dengan tugas-tugas sistem administrasi pemerintahan (Edi, 2020).

Jadi, pajak yaitu iuran wajib oleh rakyat kepada negara dan harus dibayarkan ke Negara sesuai dengan aturan yang sudah diputuskan.

Pembahasan tentang zakat dan pajak merupakan hal yang tak asing lagi bagi seorang masyarakat muslim dan juga warga berkenegaraan, tentunya setiap warga negara yang beragama Islam memiliki kewajiban membayar zakat dan juga warga Negara wajib membayar pajak.

Tentunya sudah banyak dilakukan penelitian tentang Zakat dan Pajak, namun yang membedakan penelitian ini dengan penelitian lainnya adalah peneliti membahas pelaksanaan zakat dan pajak perbandingan antara Malaysia dan Indonesia.

\section{B. METODE PENELITIAN}

Penelitian ini menggunakan metode studi literature dengan jenis pendekatan kualitatif. Kemudian, jenis penelitian yang digunakan untuk mendapatkan data yang bersifat teoritis sebagai landasan ilmiah yaitu dengan memilih dan menganalisis literature yang relevan, sesuai dengan judul yang akan diteliti (Hadi, 2004).

Dalam penelitian ini, setelah pengumpulkan beberapa literature dan tulisan-tulisan dari berbagai sumber yang dibutuhkan untuk mencari data yang diperlukan oleh peneliti, selajutnya dianalisa untuk mendapatkan kesimpulan dan kesesuaian berdasarkan judul tentang "Zakat dan Pajak: Perbandingan Malaysia dan Indonesia".

\section{HASIL DAN PEMBAHASAN}

\section{Hasil}

\section{a. Perbedaan Zakat dan Pajak}

1) Berdasarkan sumbernya, zakat diperintahkan berdasarkan dalil Allah swt. yang mana mewajibkan setiap umat Islam untuk mengeluarkan zakat sebagai bentuk Iman. Sedangkan zakat diperintahkan berdasarkan Undang-Undang yang telah disetujui oleh para petinggi pemerintah atau DPR.

2) Berdasarkan tujuannya, zakat ditujukan langsung kepada orang yang membutuhkan dan yang berhakmenerimanya, sedangkan pajak dgunakan untuk hal yang leboh luas lagi yakni untuk membiayai kebutuhan Negara baik berupa pembangunan infrastuktur pembangunan dan juga dilokasikan untuk meratakan sosial masyarakat.

3) Berdasarkan kewajibannya, zakat diwajibkan hanya untuk setiap umat Islam, sedangkan pajak diwajibkan untuk seluruh masyarakat dengan ketentuan yang telah ditentukan oleh pemerintah.

4) Berdasarkan ketentuan jumlahnya, dalam zakat terdapat ketentuan zakat yang harus dibayarkan sesuai dengan harta yang dimiliknya ketika telah memenuhi 
nishab atau batas minimal dari zakat, akan tetapi pajak tidak memiliki ketetapan yang jelas mengenai nominalnya (Edi, 2020).

\section{b. Persamaan Zakat dan Pajak}

1) Berdasarkan unsurnya, yakni paksaan dan kewajiban. Yang mana cara untuk mendapatkan pajak itu juga ada didalam zakat. Bilamana seorang muslim terlambat mebayarkan zakatnya karena keimanan dan keislamannya yang belum kaut, maka dari sini pemerintah Islam akan memaksakan bahkan memerangi mereka yang tidak bersedia membayakan zakatnya.

2) Berdasarkan pengumpulannya, jika pajak harus dibayarkan kepada lembaga yang dinaungi oleh negara, zakat juga demikian karena zakat harus diserahkan pada pemerintah sebagai amil zakat.

3) Berdasarkan ketentuannya, pembayar zakat (muzakki) dan pembayar pajak tidak akan memperoleh imbalan.

4) Berdasarkan tujuannya, zakat dan pajak sama-sama memiliki tujuan yang maslahat seperti ekonomi dan kemasyarakatan (Edi, 2020).

\section{Pembahasan}

\section{a. Pengelolaan Zakat di Malaysia}

Setiap negara bagian di Malaysia mempunyai Undang-Undang Zakat tersendiri, dibentuk oleh Majelis Perundang dari masing-masing wilayah Negara bagian. Terkhusus untuk zakat pendapatan dikenai biaya yang wajib dibayakan oleh orang yang beragama Islam berdasarkan fatwa Mufti dan diberiahukan melalui kabar Kerajaan No. (PNM-0020 Klt. 2; PUN (M) 351/27 tertanggal 22 Mei 2000). Oleh karena itu, pendapatan zakat di semua negara bagian diperlakukan dengan sama dan ditentukan oleh pemerintah pusat (Djamal, 2001).

Kebebasan pada setiap warga negara bagian terhadap undang-undang zakat menimbulkan munculnya beberapa perbedaan baik dari segi isi, aturan tata cara untuk mengelola dan juga pelaksanaan zakat pada masing-masing wilayah. Namun, isi dari semua Undang-Undang yang dibuat mengatur pada dasar yang sama. Beberapa hal umum mengenadi hukum yang mengatur pengelolaan zakat meliputi dasar dan hukum kesalahan yang enggan membayar zakat dan enggan membayar melalui petugas resmi atau lemabaga resmi.

Diantara beberapa peraturan perundang-undang di Malaysia, pelanggaran yang mengakibatkan sanksi adalah penolakan yang disengaja atau sengaja mengabaikan pembayaran zakat fitrah melalui amil yang telah ditunjuk atau disetujui oleh majelis yang telah diberi kuasa untuk memungut pajak. Sanksi atau denda yang dikenakan berbeda pada setiap wilayah negara bagian, tergantung pada undang-undang pada masing-masing negara bagian (Kuntarno, 2006)

Secara administratif, pengelolaan zakat di Malaysia berada dibawah naungan Manjelis Ugama Islam. Koordinasi Majelis Ugama Islam terjadi di dalam badan nondepartemen yang bertanggung jawab atas pembentukan lembaga strategis yang melapor 
langsung ke Perdana Menteri. Dalam aturan Menteri ini terdapat sejumlah lembaga yang berada di setiap wilayah, seperti Jabatan Kemajuan Islam yang berada di Malaysia dan Majelis Agama Islam di setiap negara bagian. Majelis Agama Islam merupakan badan wewenang yang bertanggung jawab atas urusan Agama Nasional, termasuk penyelenggaraan zakat. Selan itu juga terdapat lembaga lain yang mengurus jabatan Wakaf, Zakat dan Haji. Posisi ini dikoordinasikan dengan Majelis Agama Islam negara bagian mengenai pengumpulan, pengelolaan dan pendistribusian zakat (Pusat Pemungutan Zakat, 2003).

Di malaysia, zakat tidak dikumpulkan atau didistribusikan secara terpusat, melainkan dikelola oleh setiap negara bagian yang memiliki otoritas penuh dalam mengelola. Setiap negara bagian memiliki organisasi zakat berupa perusahaan swasta yang mengelola zakat dan Baitul Maal atau Jawatankuasa Zakat di bawah Majelis Ugama Islam Negeri dengan kebijakan, tujuan dan fungsinya sendiri. Di beberapa negara bagian, kedua organisasi ini yang melaksanakan mengumpulkan dan mendistribusikan zakat (Abdullah, 2003).

Penyaluran dzakat akan diberikan kepada asnaf-asnaf secara langsung kepada penerimanya. Di wilayah negara bagian, badan yang berwenang untuk menyalurkan zakat yaitu Baitul Maal. Batul Maal MAIWP yang memiliki cara tersendri dalam memutuskan penerima zakat.

Dilakukannya zakat dalam Undang-Undang pajak di Malaysia berdasarkan Pasal 6A ayat 3, Undang-Undang Pajak Penghasilan Tahun 1967. Berdasarkan ketentuan ini, pembayaran zakat akan dipotong dari pajak yang dipungut jika bukti pembayaran zakat dilampirkan dengan surat pernyataan dari kantor LHDBM. Penerima pendapatan niralaba menunjukkan bukti pembayaran kepada lembaga zakat atau komite yang telah disetujui oleh Negara. Pembayaran zakat individu diperolehkan selama jumlah pajak tidak melampaui batas pajak yang dibayarkan. Zakat yang dibayarkan tidak boleh melebihi tarif yang ditentukan yaitu sebesar 2,5\% (Farid, 2008).

\section{b. Pengelolaan Zakat dan Pajak di Indonesia}

Sejak awal tahun masuk Islam Negara Indonesia, telah mempraktekkan zakat dengan dorongan dua lembaga keagamaan besar, seperti masjid dan pesantren. Akan tetapi, bukti bahwa zakat secara resmi dikumpulkan tanpa campur tangan pemerintah itu tidak ada. Kemudian, pada awal orde baru, Departemen Agama berharap pemerintah terlibat dalam pengelolaan zakat untuk memaksimalkan potensinya. Namun, ususlan tersebut tidak disetujui oleh Kongres dan Presiden Soeharto. Menariknya, ketika dalam situasi yang tidak pasti atas kebijakan nasional tentang penyelenggaraan Zakat dan kurangnya sokongan dari pimpinan yang didaktor saat itu, muncullah beberapa lembaga amil zakat di beberapa daerah, kemudian Gubernur Provinsi DKI Ali Sadikin menetapkan surat keputusan pada tanggal 4 Desember 1968 tentang penyusunan Badan Amil Zakat, Infak, dan Sedekah (BAZIS). (BAZIS, 2006).

Selanjutnya, bermunculan beberapa lembaga amil zakat dengan jenis baru yang didirikan oleh badan usaha milik Negara seperti BAMUIS BNI (1968), LAZ YAUMIL PT Bontang LNG (1986), dan Baitul Mal Pupuk Pujang (1994). Sejalan dengn perkembangan 
BAZIS pada saat itu, lahirlah Undang-Undang pada tahun 1999 yaitu UU nomor 38 tahun 1999 tentang pengelolaan Zakat. Yang sekarang ini bernama BAZNAS (Badan Amil Zakat Nasional), serta pengelolaan zakatnya dibantu oleh Badan Amil Zakat (BAZ) dan Lembaga Amil Zakat (LAZ) (Eri, 2004).

Dalam Pasal 1 Ayat 1, kegiatan zakat berarti perencanaan, pengorganisasian, pelaksanaan dan pemantauan kegiatan yang berkaitan dengan pengumpulan, pendistribusian dan pengunaan zakat. Pengelolaan zakat didasarkan pada Iman dan Taqwa, keterbukaan dan kepastian hukum sesuai dengan Pancasila dan UUD 1945. Selanjutnya, zakat dikendalikan oleh Badan Amil Zakat (BAZ) dengan ketentuan, yakni:

1) Presiden dengan usul dari Menteri, lingkup Nasional,

2) Gubernur dengan usul dari Kepala Departemer Agama Provinsi, ligkup Daerah,

3) Bupati atau Walikota usul dari Kepala Departemen Agama Kabupaten atau Kota, lingkup Kabupaten atau Kota,

4) Camat dengan usul dari Kepala Kantor Urusan Agama Kecamatan, Lingkup Kecamatan.

Badan Amil Zakat (BAZ) bertanggung jawab atas perhimpunan, penyaluran, dan penggunaan zakat yang sesuai peraturan. Semua tingkatan BAZ memiliki hubungan koordinatif, konsulatif, dan informative. Pengelola mencakup masyarakat biasa dan orang pemerintahan yang memenuhi syarat.

Yang menjadi objek zakat berdasarkan dalam Pasal 11 Nomor 13 Tahun 1999, yakni Zakat Fitrah dan Zakat Harta. Dapat berupa emas, perak, uang, perdagangan, perusahaan, pertanian, perkebunan, perikanan, pertambangan, jasa dan juga rikaz.

Dalam Pasal 14 Ayat 3, menjelaskan bahwa zakat yang telah dibayarkan kepada BAZ atau LAZ dikurangkan dari penghasilan kena pajak atau sisa penghasilan wajib pajak yang bersangkutan sesuai dengan ketentuan peraturan perundang-undang yang berlaku. Berdasarkan pasal tersebut, apabila zakat telah dibayarkan oleh muzaki dan sesuai ketentuan yang telah ada dan berlaku maka, bisa dipotong dari penghasilan kena pajak atau sisa penghasilan kena pajak.

Undang-Undang Nomor 17 Tahun 2000 menyatakan bahwa wajib pajak orang pribadi dan badan dapat memotong zakat yang telah dibayarkan dari penghasilannya untuk menentukan pajak penghasilan. Jika zakat yang ditunaikan berisi penghasilan yang sesuai dengan jumlah pajak maka tidak dikenakan pajak dan zakat yang dibayarkan tidak dapat dikurangkan.

Terdapat hal yang wajib dipatuhi oleh wajib pajak bila akan mengurangkan zakat penghasilan, yakni:

1) Pemotongan zakat dari penghasilannya harus melampirkan salinan pernyataan atau pernyataan pertama yang disahkan oleh BAZ atau LAZ yang menerima pembayaran zakat yang sesuai pada SPT Tahunan Pajak Penghasilan tahun pajak dilakukannya pengurangan zakat atas penghasilan tersebut.

2) Apabila penghasilan dinyatakan dalam SPT tahunan, zakat atas pengasilah tidak dibayarkan, zakat dapat mengurangi zakat paa tahun pajak dimana pembayar itu 
dilakukan, selama Wajib Pajak dapat membuktikan penghasilannya dan dinyatakan dengan bukti SPT tahun pajak sebelumnya.

3) Pengurangan zakat dari penghasilan berasarkan Pasal 1 akan dilakukan pada tahun dimana SPT Tahunan Wajib Pajak melaporkan penghasilannya, tergantung pada tahun penghasilan itu dikumpulkan atau diperoleh.

4) Surat setoran Zakat yang dapat diakui sebagai alat bukti antara lain adalah nama, alamat lengkap, Nomor Pokok Wajib Pajak (NPWP), jenis penghasilan yang dibayarkan ke zakat, sumber atau jenis penghasilan, bulan atau tahun penghasilan, jumlah penghasilan, dan besarnya zakat terkait dengan pendapatan.

Kemudian terdapat penyempurnaan tentang Zakat dan Pajak dalam UUD No. 23 Tahun 2011, terdapat 2 Pasal tentang perpotongan zakat dan pajak yakni Pasal 22 dan 23. Dalam pasal 22 menyatakan bahwa zakat yang dibayarkan oleh muzaki kepada BAZNAS atau LAZ dikurangkan dari penghasilan kena pajak. Kemudian, dalam pasal 23 ayat (1) BAZNAS atau LAZ wajib memeberikan bukti setoran zakat kepada muzaki, ayat (2) bukti setoran sebagaimana yang dimaksud pada ayat (1) digunakan sebagai pengurang penghasilan kena pajak (Farid, 2008).

\section{KESIMPULAN}

Pengeloaan zakat di Malaysia dikategorikan menjadi 3 bentuk; Pertama, sistem korporasi dimana pengelolaan pengumpulan dan pendistribusian zakat dikelola oleh sebuah korporasi; kedua, sistem semi korporat dimana perusahaan hanya mengelola proses pemungutan zakat dan pendistribusiannya dikendalikan langsung oleh pemerintah negara bagian; dan ketiga, penguasaan zakat sepenuhnya menjadi tenggung jawab pemerintah daerah bagian atau Majelis Ugama Islam. Di Malaysia, zakat diklaim bisa menjadi pengurang atas kewajiban pepajakan. Ini terjadi ketika muzaki membayar zakat ke lembaga yang telah diakui oleh kerajaan seperti Pusat Pemungutan Zakat (PPZ), sehingga jika muzaki membayarkan zakat pada PPZ maka, ada pengurangan zakat untuk pengurangan pajak.

Sedangkan pengelolaan zakat di Indonesia sendiri dilaksanakan oleh Badan Amil Zakat Nasional (BAZNAS) dan Lembaga Amil Zakat (LAZ) yang mana lembaga ini disusun oleh pemerintah, baik dari tingkatan Nasional hingga Kecamatan. Kemudian di tahun 1999 terdapat sinergi awal antara Zakat dan Pajak sebagaimana dalam Undang-Undang Nomor 38, kemudian didukung dengan adanya Undang-Undang Nomor 17 tentang Pajak Penghasilan Tahun 2000, dan juga disempurnakan dengan Undang-Undang Nomer 22 dan 23 Tahun 2011. Sehingga terdapat regulasi antara keduanya, yang mana terdapat pemotongan zakat dan pajak apabila zakat yang disetorksn oleh muzaki melalui BAZNAS atau LAZ dengan menyertakan bukti setoran pajak. 


\section{DAFTAR PUSTAKA}

Al-Qur'an al-Karim

Aflah, Kunarto Noor. Tajang, Mohd Nasir. Zakat dan Peran Negara. cet. Pertama. Jakarta: Forum Zakat, 2006.

BAZIS, Manajemen ZIS Bazis Provinsi DKI Jakarta. cet. Pertama. Jakarta: Bazis, 2006.

Doa, Djamal. Menggagas Pengelolaan Zakat Oleh Negara. Cet. Pertama. Jakarta: PT. Nuansa Madani, 2001.

Hafiduddin, Didin. Anda Bertanta Tentang Zakat, Infak dan Sedekah Kami Menjawab. Cet. Pertama. Jakarta: PT. Kautsar Prima, 2008.

Haskar, "Edi. Hubungan Pajak dan Zakat Menurut Perpektif Islam”. Menar Ilmu, No. 02. April, 2020.

Nadhari, Abdullah Khatib. "Pengelolaan Zakat di Dunia Muslim". Economic: Jurnal Ekonomi dan Hukum Islam, No. 2, 2003.

Pusat Pemungutan Zakat MAIWP, Laporan Zakat 2003.

Rauf, Fathurrahman. Zakat Untuk Pengentasan Kemiskinan, Cet. Pertama. Jakarta: PP. LAZIS NU 2009.

Ridwan, Murtadho. "Zakat Vs Pajak: Studi Perbandingan Di Beberapa Negara Muslim”,. Jurnal Zakat dan Wakaf. No. 1. Juni, 2014.

Sutrisno, Hadi. Metodologi Research Jilid 2. Yogyajarta: Andi Offset, 2004.

Wajdi, Farid. Kajian Penerapan Zakat Sebagai Kredit Pajak Dalam Pajak Penghasilan Orang Pribadi Di Indonesia, Skripsi. Depok: Universitas Indonesia, 2008 